\title{
Massive Open Online Courses in the Initial Training of Social Science Teachers: Experiences, Methodological Conceptions, and Technological Use for Sustainable Development
}

\author{
Delfín Ortega-Sánchez ${ }^{1, *(1)}$ and Isabel María Gómez-Trigueros ${ }^{2}$ \\ 1 Department of Specific Didactics, Faculty of Education, University of Burgos, 09001 Burgos, Spain \\ 2 Department of General Didactics and Specific Didactics, Faculty of Education, University of Alicante, \\ 03690 Alicante, Spain; isabel.gomez@ua.es \\ * Correspondence: dosanchez@ubu.es; Tel.: +34-947-111-832
}

Received: 28 December 2018; Accepted: 18 January 2019; Published: 22 January 2019

\begin{abstract}
This article analyzes, on the one hand, the perception of future teachers $(n=162)$ on the degree of acquisition of the Digital Teaching Competition (CCD) in the teachers' formative contexts. On the other hand, this article analyzes future teachers' social representations about the potential contribution of educational technologies, in particular the massive open online courses (MOOCs), to comply with the Sustainable Development Goals (SDGs). A questionnaire validated by three Spanish universities is applied, and a quantitative analysis of the data is used. The results obtained inform the educational need to transfer the progress and generalization of information and communication technologies (ICT) for education for sustainable development in teacher training curricula.
\end{abstract}

Keywords: teacher training; digital teaching competence; sustainable development; Social Sciences

\section{Introduction}

Massive open online courses (MOOCs), a term coined in 2008 by Dave Cormirer and Bryan Alexander to refer to the online courses designed by George Siemens and Stephen Downes [1], are considered, like other virtual environments, to be part of Educational Software 3.0. This tool, which is based on the connectivist principles of massiveness, being free of charge, portability, ubiquity, self-assessment, modularity, and video simulation, proposes new teaching-learning scenarios for the creation/production of content, and the active, interactive, and collaborative role of students in guided and flexible learning environments.

The founding of providers such as Udacity and Coursera in 2012 gave the first boost to the offering of these MOOCs [2], and to the gradual improvement of their platforms. Today, these courses are classified mainly as cMOOCs, which are developed from the experimental principles of connectivist learning; xMOOCs, which follow more traditional educational approaches, and the subtypes derived from them (TransferMOOCs, MadeMOOCs, SynchMOOCs, AsynchMOOCs, AdaptiveMOOCs, GroupMOOCs, ConnectivistMOOCS, and MiniMOOCSs) [3]; or Micro-NOOC [4]. In terms of design, the courses share technological innovation, which is understood as the improvement of teaching and learning processes. In structural designs offered by the various platforms, their methodological distinctiveness is evident, being removed from the specific characteristics of traditional digital repositories. MOOCs therefore provide an opportunity to establish synergies between universities and the knowledge society, creating a new and burgeoning space for collaborative learning that meets 
current educational requirements [5], as well as for internationalization, recognition, and the opening up of universities [6-9].

The experience of social interaction and social or socio-technological connectivity provided by MOOCs encourages the achievement of objectives in a specific area [10]. Indeed, individual and group activities; the use of initial, specific, and self-created multimedia resources (open educational resources); the operational implementation of social networks, such as Twitter, LinkedIn, and Facebook, and the application of self- and co-assessment systems [11], together with instructions on how to monitor or facilitate autonomous learning and guarantee permanent learning that can be transferred to different contexts. Furthermore, institutional affiliation is not required to take a MOOC. These courses tend to scale, leading to the construction of virtual learning communities through the democratization of knowledge and digital competencies, and they have a major impact in line with their massive nature, capable of organizing sub-networks of lifelong learning, ongoing training, and professional development. The socio-educational impact of this transfer is starting to give rise to a significant volume of scientific work [12,13].

The dynamism of MOOCs responds suitably to the new forms of construction, appropriation, and interactive exchange of knowledge in higher education. This is in keeping with the competency needs of potential students, and with precise transferability to personalized professional and social contexts [14].

\section{Massive Open Online Courses and Education for Sustainable Development}

The overwhelming spread of MOOCs in Spain in 2013 [15], through platforms such as Unx, MiríadaX, UPVX, and UnedComa, did not lead to the creation of courses oriented towards the training of social science teachers [16,17]. This was despite the cross-cutting nature of social science and special interest in its teachers' teaching and learning. In this respect, given the fact that education for sustainable development and for human rights and democratic values (the bases of the 2030 agenda) is one of the concerns of teachers and researchers working on social science teaching, the lack of MOOCs is surprising. MOOCs are sustainable models of teaching-learning [18] that are intended to be used for these educational purposes at the Ibero-American and international level.

As in other countries, education for sustainable development continues to be a pedagogical challenge for schools $[19,20]$ and initial teacher training. In the Spanish curriculum, the content of education for sustainable development, which is fundamentally associated with the natural environment and scientific culture, does not include other content on human rights, inclusion, diversity and social plurality, or equality of gender and opportunity, which are essential social aspects in education to create democratic, participatory, and committed citizens. This distancing of the conceptual interdependence between nature and society, and between global justice and sustainability, causes the fragmentation of the fundamental bases of education for sustainable development through citizen participation [21] in the context of education for global citizens [22].

The current information and communication society (ICS) asks capable education professionals to implement information and communication technologies (ICTs) in their daily teaching practice, through the acquisition and development of digital teaching competence from three dimensions: technological knowledge (TK), pedagogical knowledge (PK), and content knowledge (CK) [23]. From this perspective, MOOCs are proposed as an excellent opportunity for the development and acquisition of professional skills (including digital teaching), oriented towards the interdisciplinary training of future teachers for sustainable development. In this sense, despite their limitations (e.g., drop-out rate, lack of official credentials for attending and passing courses, establishment of more defined assessment systems), MOOCs facilitate access to and transfer of knowledge through innovation and citizen empowerment for social progress. In this context, the present study asks the following research questions:

- What is the perception of future teachers (digital natives) of their digital teaching competence (DTC)? 
- What factors determine the social representations of the potential contribution of ICTs in general, and of MOOCs in particular, to the teaching and learning of sustainable development goals (SDGs)?

- Do these representations appear to be determined by gender and education?

\section{Objectives}

The study presented here intends to delve more deeply into two basic aspects of teaching training. It first seeks to analyze the perception of teaching training students with regard to their degree of DTC. It also seeks to study students' social representations of the potential contribution of technologies to meeting the seventeen SDGs and 169 targets over the next 15 years. The following objectives are therefore proposed:

- Determine and describe the level of DTC in the participating students, as well as their perceived utility of ICTs for their teaching.

- Analyze students' appraisal of the importance of reducing the "digital divide", and the role of ICTs and MOOCs in the convergence of communication and development on a global level.

- $\quad$ Observe the behavior of the data and results obtained, based on the participants' gender and teacher training.

\section{Material and Method}

\subsection{Sample}

The target population for the study was selected in a non-probabilistic, targeted, and intentional fashion [24,25], and was comprised of 162 participants who were trainee teachers in the Bachelor of Primary Education and the Master of Secondary Education programs. The sample was considered large compared with the total size of the target population [26,27], and included 98 women $(60.5 \%)$ and 64 men (39.5\%). Their ages ranged from 18 years to over 40 years (Table 1), with an average age of 21.7 years $(\mathrm{SD}=3.75$; range $=18-41)$. Their distribution by year of study was as follows: first year $(6.8 \%)$, second year $(24.1 \%)$, third year $(40 \%)$, and fourth year $(2.1 \%)$ of the Bachelor of Primary Education program ( $73 \%$ of the sample). The other $27 \%$ were completing their Master of Secondary Education.

Table 1. Cross table of descriptive values: age range, course of study, and gender.

\begin{tabular}{ccccc}
\hline \multirow{2}{*}{ Age Range } & $\begin{array}{c}\text { Bachelor of } \\
\text { Primary Education }\end{array}$ & $\begin{array}{c}\text { Master of Secondary } \\
\text { Education }\end{array}$ & \multicolumn{2}{c}{ Gender } \\
\cline { 4 - 5 } 18 years & 11 & 0 & 9 & Memale \\
19 years & 39 & 0 & 29 & 10 \\
20 years & 27 & 0 & 15 & 12 \\
21 years & 17 & 0 & 7 & 10 \\
22 years & 18 & 27 & 25 & 20 \\
Between 23 and 29 & 6 & 12 & 8 & 10 \\
years & 1 & & 5 & 0 \\
Between 30 and 40 & 0 & 4 & 0 & 0 \\
years & 119 & 0 & 98 & 64 \\
Over 40 years & & 43 &
\end{tabular}

\subsection{Design and Procedure}

This study gathered descriptive information using a quantitative work model [28], and used an online questionnaire in learning contexts within the Faculty of Education at the University of Burgos and the University of Alicante (Spain). It used a non-experimental exploratory research design, based 
on the use of a questionnaire as an instrument to collect information [29,30]. The study was conducted during the 2017-2018 academic year over four phases of work [23]: (1) a theoretical review of trainee teachers' DTCs and their training on content related to sustainable development and the digital divide; (2) the design and subsequent validation of the instrument through the collaboration of teachers from other national universities; (3) the subsequent collection of information through field work at two Spanish universities; and (4) the analysis of the data obtained and the drafting of lesson plans for the work on SDGs in teacher training, using knowledge of social science teaching.

The questionnaire was sent by email through the free application Google Forms during the second semester of the 2017-2018 academic year. Students received the email through their institutional email account. They were informed of the objective of the research, as well as the fact that responses would be confidential.

\subsection{Instrument}

The variables studied were measured using the questionnaire proposed by Ortega and Gómez [16]. The questionnaire was adapted for the research objectives and validated by experts from the public universities of Burgos, Alicante, Murcia, and the Balearic Islands. This instrument was made up of 19 items organized into three content blocks: the first was about the socio-demographic characteristics of the sample (items 1-4); the second focused on knowledge about MOOCs and their role in teacher training (items 5-8); and the third was about students' perceptions of the relationship between sustainability and ICTs (items 9-19) (https://goo.gl/forms/rI5o72R7ilO4fM4n1). All of the items were answered using a five-point Likert scale ranging from 1 ("Strongly disagree") to 5 ("Completely agree").

To confirm the internal consistency and reliability of the questionnaire, psychometric tests were performed, in order to determine the reliability of the measurement scale. Specifically, the reliability of $\alpha=0.881$ was found in the Cronbach's alpha test, establishing high and adequate internal consistency of the instrument for the proposed study [31,32].

Furthermore, to determine the validity of the instrument's internal structure, a principal component factor analysis was performed, so as to identify latent factors lying beneath the manifest variables, as well as the patterns of relationships between latent and manifest variables. To do so, KMO and Bartlett's test were used (Table 2). From the data obtained, it can be concluded that the exploratory factorial analysis is possible, given that the $p$ value (significance) was $<0.05$ and the correlation between all of the variables was high (the value obtained in the KMO test was 0.791 ).

Table 2. KMO and Bartlett's test.

\begin{tabular}{llr}
\hline Kaiser-Meyer-Olkin measurement of sampling adequacy & 0.791 \\
& Approx. Chi-squared & 1043.221 \\
Barlett's test of sphericity & gl & 105 \\
& Sig. & 0.000 \\
\hline
\end{tabular}

A varimax rotation of components was also performed, in which it was found that the total variance explained by the first two components was $64.51 \%$ of the total variance explained. The component matrix informed us of the relationship between the variables by grouping them, thus reducing the original data to two main components (Table 3), which appeared to include all of the items analyzed.

The first component appeared to collect students' perceptions of the MOOC-digital divide-sustainable development concept, as well as its perceived utility as a training resource for the teaching of the social sciences (items $5,6,7,8,9,11,12$ ). The second component grouped together questions on ICTs as tools for the convergence of communication and the reduction of the latent digital divide, and for the promotion of changes, through the implementation of technologies, to countries' economic development (items 10, 13, 14, 15, 16, 17, 18, 19). 
Table 3. Rotated component matrix. The extraction method was principal component analysis, and the rotation method was Varimax with Kaiser normalization.

\begin{tabular}{ccc}
\hline \multirow{2}{*}{ Item } & \multicolumn{2}{c}{ Component } \\
\cline { 2 - 3 } & $\mathbf{1}$ & $\mathbf{2}$ \\
\hline 7 & 0.872 & \\
8 & 0.868 & \\
11 & 0.728 & \\
5 & 0.611 & \\
6 & 0.584 & \\
14 & & 0.810 \\
16 & & 0.771 \\
15 & & 0.659 \\
18 & & 0.654 \\
19 & & 0.613 \\
10 & & 0.482 \\
9 & 0.757 & \\
12 & 0.684 & \\
13 & & 0.533 \\
17 & & 0.538 \\
\hline
\end{tabular}

\subsection{Data Analysis}

For the analysis of data, descriptive statistics were calculated (means and standard deviation) using Statistical Package for the Social Sciences (SPSS) version 23 for Windows. The normal distribution of the sample was confirmed, as was the homogenization of the variances of the different analyses. In the same way, means were compared using the $t$-test for independent samples, and a one-way analysis of variance (ANOVA test) was performed so as to compare the results based on gender, age, and level of studies.

\section{Results}

\subsection{Analysis of the Descriptive Data}

Firstly, the descriptive statistics (mean and standard deviations) are presented for each item (Table 4). In general, the results indicated that students' perceptions of MOOCs as resources for their own training and their future work as teachers were positive, as can be seen in items 7 and $8(M \geq 4.00$; $\mathrm{SD} \leq 0.840)$. This highlights the importance that students attribute to these types of courses for their training as teachers. As can be seen in the results, the majority of the sample knew what a MOOC was and have completed one (item $5: M=3.94 ; \mathrm{SD}=0.637$; and item $6: M=4.07 ; \mathrm{SD}=0.670$, respectively).

With regard to the perceived utility of ICTs (item 10: SD = 3.81) and MOOCs (item 11: $M=3.76$ ) in reducing the "digital divide", the data obtained show a mean under 4.0, which indicates an only slightly positive appraisal of these resources, with a majority of participants responding "Neither agree nor disagree". Such values contrast with the students' knowledge of the concept of the "digital divide", for which a mean over 4.0 was observed (item 9: $M=4.02$ ). This corresponded to the option "Agree" in most of the responses obtained. In the same way, participants also seemed to recognize the concept of "sustainable development", with a high number of "Agree" responses (item 12: $M=4.14$; $\mathrm{SD}=0.695)$. 
Table 4. Descriptive results (M: mean; SD: standard deviation).

\begin{tabular}{|c|c|c|c|}
\hline Item & Descriptor of the Statement Being Analyzed & $M$ & SD \\
\hline 5 & I am familiar with the concept of MOOC and I understand what it means. & 3.94 & 0.637 \\
\hline 6 & I have participated in a MOOC as a student. & 4.07 & 0.670 \\
\hline 7 & I believe that MOOCs help me in my training as a future teacher. & 4.01 & 0.888 \\
\hline 8 & $\begin{array}{l}\text { MOOCs are useful resources for the teaching and learning of social } \\
\text { sciences. }\end{array}$ & 4.04 & 0.849 \\
\hline 9 & I am familiar with the concept of "digital divide". & 4.02 & 0.842 \\
\hline 10 & I believe that ICTs help to eliminate the current "digital divide". & 3.81 & 0.831 \\
\hline 11 & $\begin{array}{l}\text { ICT resources such as MOOCs help to reduce the existing "digital } \\
\text { divide". }\end{array}$ & 3.76 & 0.667 \\
\hline 12 & I know what "sustainable development" means. & 4.14 & 0.695 \\
\hline 13 & $\begin{array}{l}\text { As facilitators of solutions, ICTs help drive sustainable development so } \\
\text { that the sustainable development goals (SDGs) can be achieved. }\end{array}$ & 3.38 & 0.679 \\
\hline 14 & $\begin{array}{l}\text { ICTs can be important levers for a country's economic and social } \\
\text { development. }\end{array}$ & 4.00 & 0.768 \\
\hline 15 & $\begin{array}{l}\text { I believe that ICTs can help slow down problems with CO2 emissions and } \\
\text { the consumption of primary energies through the promotion of } \\
\text { teleworking, the use of online learning resources such as MOOCs, } \\
\text { electronic invoicing, teletraining, or the use of online forms. }\end{array}$ & 3.64 & 0.911 \\
\hline 16 & $\begin{array}{l}\text { Improved connectivity and access to ICTs help the convergence of } \\
\text { communication and development on a global level. }\end{array}$ & 4.04 & 0.704 \\
\hline 17 & $\begin{array}{l}\text { My training on ICTs included content, procedures and values related to } \\
\text { sustainable development. }\end{array}$ & 2.88 & 0.776 \\
\hline 18 & $\begin{array}{l}\text { The inclusion of ICTs in the teaching and learning of social sciences } \\
\text { enables lesson plans that help eradicate the existing problems of } \\
\text { unsustainability to be developed. }\end{array}$ & 3.99 & 0.703 \\
\hline 19 & $\begin{array}{l}\text { I believe that ICTs used in education can contribute to the promotion of } \\
\text { social inclusion, the improvement of public health services, the } \\
\text { elimination of gender differences in access to work, culture and } \\
\text { information, and improve help for people who live alone through, for } \\
\text { example, wireless connections and remote sensing. }\end{array}$ & 4.14 & 0.654 \\
\hline
\end{tabular}

With regard to future teachers' appraisal of the relationship between sustainability and the use of technologies, the results showed a negative perception. Thus, in items 13 and 15, which were about the utility of ICTs in achieving the SDGs, a mean value under 4.0 was obtained in both cases (item 13: $M=3.38 ; \mathrm{SD}=0.679$; item $15: M=3.64 ; \mathrm{SD}=0.911$ ). This indicates that a majority of participants responded "Neither agree nor disagree".

This was not the case with their positive appraisal of technologies as a lever for global economic and social development, with a majority of participants responding "Agree" (item 14: $M=4.00$; $\mathrm{SD}=0.768$; item $16: M=4.04 ; \mathrm{SD}=0.704)$. In the same way, the sample considered that including ICTs in the teaching and learning process for the social sciences may contribute to reducing the current problems of unsustainability and promoting the generation of new thoughts among the population (item 18: $M=3.99 ; \mathrm{SD}=0.703$; item 19: $\mathrm{M}=4.14 ; \mathrm{SD}=0.654$ ).

With regard to training received on the interrelation between ICTs and sustainable values, students believed that they were not appropriately trained to implement technologies from that perspective, as shown by the values for item $17: M=2.88$ and $\mathrm{SD}=0.776$. Therefore, the participants believed they lack sufficient training on sustainability-related technological resources to be able to implement this knowledge adequately in their future work as teachers.

\subsection{Comparative Analysis Based on Gender and Course of Study}

Following the descriptive analysis of the items, a comparison of means was conducted using the independent samples $t$-test, as well as a one-way ANOVA (Table 5). The intention was to compare and assess whether or not there were significant differences based on gender and the course of study of the individuals who made up the sample, with regard to the three blocks analyzed. 
Table 5. Independent samples $t$-test and one-way ANOVA test based on gender.

\begin{tabular}{|c|c|c|c|c|c|c|}
\hline \multirow{2}{*}{ Item } & \multicolumn{2}{|c|}{ Gender } & \multicolumn{2}{|c|}{$t$-test } & \multicolumn{2}{|c|}{ ANOVA } \\
\hline & $\mathbf{F}$ & $\mathbf{M}$ & $t$ & p & $\mathbf{F}$ & $\mathrm{p}$ \\
\hline 5 & 3.50 & 3.55 & -4.441 & 0.015 & 10.186 & 0.000 \\
\hline 6 & 3.94 & 4.27 & -3.117 & 0.226 & 2.134 & 0.002 \\
\hline 7 & 3.69 & 4.23 & -4.248 & 0.001 & 54.531 & 0.001 \\
\hline 8 & 3.65 & 4.56 & -7.385 & 0.004 & 18.042 & 0.002 \\
\hline 9 & 3.83 & 4.05 & -1.461 & 0.026 & 9.715 & 0.146 \\
\hline 10 & 3.65 & 4.06 & -3.191 & 0.596 & 19.726 & 0.002 \\
\hline 11 & 3.50 & 4.16 & -6.969 & 0.001 & 48.560 & 0.001 \\
\hline 12 & 4.07 & 4.30 & -2.123 & 0.895 & 4.507 & 0.035 \\
\hline 13 & 3.35 & 3.47 & -1.099 & 0.240 & 1.207 & 0.274 \\
\hline 14 & 4.00 & 3.98 & 0.126 & 0.472 & 0.016 & 0.900 \\
\hline 15 & 3.53 & 3.80 & -1.833 & 0.078 & 3.358 & 0.069 \\
\hline 16 & 3.93 & 4.20 & -1.237 & 0.049 & 6.075 & 0.015 \\
\hline 17 & 2.82 & 3.02 & -1.410 & 0.035 & 1.989 & 0.160 \\
\hline 18 & 3.84 & 4.09 & -2.015 & 0.992 & 4.058 & 0.046 \\
\hline 19 & 3.98 & 4.11 & -2.465 & 0.248 & 1.530 & 0.218 \\
\hline
\end{tabular}

According to statistical Levene, equal variances for all results $(p>0.05)$.

The results showed that there were indeed significant differences between female and male participants in the study in relation to the values analyzed (Table 5). With a level of significance of $p>0.05$, the independent samples $t$-test found statistically significant differences between women $(M=3.69)$ and men $(M=4.23)$ in terms of seeing MOOCs as resources for their training as future teachers $(p=0.001$ ), which was the focus of item 7 . These differences were repeated in the perception of MOOCs as useful teaching tools for the teaching and learning of social sciences (item 8), with a mean of 3.65 for women and 4.56 for men, and a $t$-test value of $p=0.004$.

The data from item 11, which focused on the ability of MOOCs to reduce the "digital divide", should also be highlighted. There were clear differences between women $(M=3.50)$ and men $(M=4.16)$, and a $t$-test result of $p=0.001$.

Furthermore, the confidence interval limits for the difference indicated that for variables $5,6,7$, $8,10,11,12,18$, and 19, in both genders, the value " 0 " was not included in the confidence interval limits for the difference. This indicated that, for such items, the hypothesis of equal means could be rejected. This was also confirmed by the results of the $t$-test for these questions (item 5: $t=-4.441$; item 6: $t=-3.117$; item 7: $t=-4.248$; item 8: $t=-7.385$; item 10: $t=-3.191$; item 11: $t=-6.969$; item 12: $t=-2.123$; item 18: $t=-2.015$; item 19: $t=-2.465$ ).

With regard to the one-way ANOVA to compare student perceptions based on gender (Table 5), significant differences were found between women and men for items 5, 6, 7, and 8, which focused on knowledge about MOOCs and their role in teacher training. These items all had $p$ values under 0.05 . In general, it can be pointed out that for these variables, significant differences between women and men were found, with higher means for men in every case.

Something similar happened in the block of questions on student perceptions of the interrelation between sustainability and technologies, specifically in items 10,11,12, 16, and $18(p<0.05)$. The same is true of the previous block of questions. The average values for this block were also higher for men (item 10: $M=4.06$; item 11: $M=4.16$; item 12: $M=4.30$; item 16: $M=4.20$; item 18: $M=4.09$ ). 


\subsection{Correlation Between the Variables Analysed}

In order to determine the relationship between student perceptions of their training on the use of MOOCs and their appraisal of their initial training on applying ICTs for sustainable development, the Pearson correlation coefficient was calculated (Table 6).

Table 6. Pearson bivariate correlations.

\begin{tabular}{|c|c|c|c|c|c|c|c|c|c|c|c|c|c|c|c|}
\hline & 5 & 6 & 7 & 8 & 9 & 10 & 11 & 12 & 13 & 14 & 15 & 16 & 17 & 18 & 19 \\
\hline 5 & 1 & & & & & & & & & & & & & & \\
\hline 6 & $0.697^{* *}$ & 1 & & & & & & & & & & & & & \\
\hline 7 & $0.667^{* *}$ & $0.612 * *$ & 1 & & & & & & & & & & & & \\
\hline 8 & $0.678^{* *}$ & $0.634^{* *}$ & $0.836 * *$ & 1 & & & & & & & & & & & \\
\hline 9 & $0.409 * *$ & $0.374^{* *}$ & 0.148 & 0.180 * & 1 & & & & & & & & & & \\
\hline 10 & 0.243 ** & $0.192 *$ & 0.166 * & 0.251 ** & $0.325^{* *}$ & 1 & & & & & & & & & \\
\hline 11 & $0.768^{* *}$ & $0.754 * *$ & $0.875^{* *}$ & $0.837^{* *}$ & $0.373^{* *}$ & $0.551 * *$ & 1 & & & & & & & & \\
\hline 12 & $0.283 *$ & 0.228 & 0.029 & 0.070 & $0.757^{* *}$ & $0.370 * *$ & $0.257^{*}$ & 1 & & & & & & & \\
\hline 13 & 0.077 & 0.005 & 0.066 & 0.155 * & 0.024 & $0.207^{* *}$ & 0.154 & 0.131 & 1 & & & & & & \\
\hline 14 & 0.050 & 0.096 & 0.116 & 0.174 * & 0.111 & 0.633 ** & 0.143 & 0.123 & 0.262 & 1 & & & & & \\
\hline 15 & 0.126 & $0.255^{* *}$ & 0.283 ** & $0.283^{* *}$ & $0.231 * *$ & $0.674 * *$ & $0.376^{* *}$ & 0.260 ** & $0.539^{* *}$ & $0.632 * *$ & 1 & & & & \\
\hline 16 & 0.116 & 0.100 & 0.197 * & $0.249 * *$ & $0.174 *$ & 0.205 ** & $0.297 * *$ & 0.185 * & 0.005 & 0.752 ** & $0.706 * *$ & 1 & & & \\
\hline 17 & -0.088 & -0.075 & 0.105 & $0.217^{* *}$ & -0.011 & 0.188 * & $0.189 *$ & 0.050 & $0.364 * *$ & $0.182 *$ & $0.223 * *$ & $0.156^{*}$ & 1 & & \\
\hline 18 & 0.103 & $0.158 *$ & $0.633 * *$ & 0.690 ** & 0.149 & 0.730 ** & $0.332 * *$ & $0.169 *$ & $0.190 *$ & $0.744 * *$ & $0.722 * *$ & $0.334^{* *}$ & $0.360 * *$ & 1 & \\
\hline 19 & 0.079 & 0.123 & $0.697^{* *}$ & $0.696^{* *}$ & $0.246^{* *}$ & $0.732 * *$ & $0.316^{\text {** }}$ & 0.259 ** & 0.124 & $0.384 * *$ & $0.457^{* *}$ & $0.267^{* *}$ & 0.135 & 0.813 ** & 1 \\
\hline
\end{tabular}

In the results obtained, it can be seen that there was a high correlation between knowledge about MOOCs (items 5 and 6) and their being perceived as tools for teacher training (items 7 and 8 with an $r$ value $\geq 0.612 ; p=0.00$ in all correlations observed). In the same way, a high correlation was found between items 7 and 8 and the use of MOOCs to develop lesson plans on unsustainability (item 17 and 18: $r$ value $\geq 0.633 ; p=0.00$ ), as well as recognizing them as instruments to reduce the "digital divide" (item 11: $r$ value $=0.875, p=0.00$; and $r=0.837, p=0.00$, respectively). In relation to knowledge about the "digital divide" (item 9) and "sustainable development" (item 12), a highly positive correlation was confirmed $(r=0.757 ; p=0.00)$.

There was also a strong positive relationship between seeing ICTs as resources to reduce the "digital divide" (item 10), their appraisal as a lever for a country's development (item 14: $r=0.633$; $p=0.00$ ) and their appraisal as mechanisms to eradicate the problems of global unsustainability (item 18: $r=0.73, p=0.00$; item 19: $r=0.732, p=0.00$ ). In this way, a significant correlation was confirmed between the inclusion of technologies in the teaching and learning process for the social sciences (item 18) and the perceived utility of these teaching resources for a country's social development (item 14: $r=0.744, p=0.00$ ), and for the reduction of the problems of $\mathrm{CO}_{2}$ emissions and primary energy consumption, among other existing problems related to unsustainability (item 15: $r=0.722, p=0.00$ ).

However, considering ICTs as resources to achieve the SDGs (item 13) showed a positive but weak correlation with knowledge about MOOCs (item 5: $r=0.077, p=0.524$ ), the participation of the sample in MOOCs (item 6: $r=0.005, p=0.324$ ) and the students' appraisal of this type of course for teacher training (item $7: r=0.066, p=0.223$ ).

Lastly, the sample's perception of their technological training on content related to sustainable development (item 17), their knowledge about and participation in MOOCs (item 5 and 6), and their understanding of the concept of "digital divide" (item 9) were analyzed. In these interrelations, a weak negative correlation was found between items 17 and $5(r=-0.088 ; p=0.263)$, between items 17 and $6(r=-0.075 ; p=0.341)$ and between items 17 and $9(r=-0.011 ; p=0.890)$, which showed that they were inversely correlated.

\section{Discussion and Conclusions}

In the current sociocultural and educational context of the ICS, precedence has been given to the gradual inclusion of technologies in the training of future teachers. ICTs are presented as basic tools that allow the general public to access knowledge and resources offered on the web, and offer continuous learning through lifelong learning $[33,34]$. In this way, it proves indispensable that new 
generations of teachers acquire in their training an appropriate level of digital competence [35], defined not as mere activities concerning instrumental training, but as giving students the skills that allow them to access the content of the ICS, critically discerning their use in teaching [16-36] and recognizing the current needs for the sustainability of the planet.

It was in the year 2000 that, faced with the imbalance of humanity in areas such as education and access to basic resources, the United Nations adopted the Millennium Development Goals (MDGs), as it had been impossible to achieve equal opportunities for all in relation to development and well-being. These MDGs guaranteed the economic and social development of humanity, with the goals set for the year 2015. Despite the achievements reached by the MDGs [37], there is still a long way to go. Therefore, the United Nations approved the so-called 2030 Agenda [38], in which the MDGs were broadened and the global commitment to continue fighting for sustainable global development was renewed. This included the SDGs that must stimulate and direct the initiatives and policies towards global sustainability throughout 2016-2030. In this way, technologies are presented as the perfect catalyst for development, where it is pointed out that the spread of ICTs in education and global interconnection can offer great potential to reduce the digital divide $[39,40]$. Therefore, it is necessary to provide appropriate training in keeping with the needs of society [41,42], which includes the need to adopt measures that are adapted for the new requirements of the ICS $[43,44]$ and the current requirements related to the SDGs [45]. These changes will only be possible if current university teachers are given digital teaching skills and subject-specific and methodological content on sustainability that allows adequate training of students, particularly in the courses of study analyzed in this study: the Bachelor of Primary Education and the Master of Secondary Education.

In this way, the research conducted found that the use of technologies is recognized as one of the competencies of today's teachers, and appears in the guidelines of the European Higher Education Area, as well as in related studies $[16,46,47]$. For this reason, it is essential to recognize which knowledge is acquired by future teachers and what perception they have of their DTCs in the formative context of their studies, so as to improve curricula and identify deficiencies in their training for appropriate professional development. In the same way, it is essential to address implementation of such technologies from a sustainable teaching dimension, which meets the current needs at the global level [48].

In view of the results obtained, it can be seen that trainee teachers have a positive view of technologies, which include MOOCs, both for the development of their own training and for their future work as teachers. These conclusions are similar to those from studies such as that of Emine et al. [49], in which the relationship between digital training and the positive reception of such tools for teaching is corroborated, or the analysis of Roig-Vila et al. [47], which found that trainee teachers did not find the manipulative use of technologies difficult.

With regard to the knowledge of concepts such as "digital divide" and "sustainable development", it was found that the teaching students' perceptions were positive and that students recognized the educational value of such content. With regard to such results, students attribute great relevance to ICTs in terms of their usefulness as resources to reduce existing socioeconomic differences and minimize problems for the development of certain geographic areas. This finding is in keeping with other studies that have addressed this same topic [50-52], and highlights that trainee teachers believe it necessary to train in digital skills, so as to include technological tools in their work. Furthermore, they underline the importance that, in such training, knowledge on the sustainable use of technological resources is acquired [53-56]. In this sense, differential results were obtained based on the gender of participants, with men attributing greater importance to digital training than women. These values must be related to the different perception that men and women have of their ability to use ICTs in a manipulative manner $[47,57,58]$. In our view, it would be interesting for future research to delve more deeply into this topic, so as to evaluate the implications of the various conceptions or perceptions of DTCs by gender-and in this way, evaluate whether there are significant variations, not only in relation 
to technical manipulation, but also in reference to adequate inclusion of ICT tools in classrooms and the sustainable teaching approach of each group.

By analyzing the correlations between the variables, it is confirmed, in line with the contributions of Gómez and Ortega [59], that students are familiar with and have participated in MOOCs, and recognize the formative value of such teaching resources for teachers. As set out in international studies on the importance of ICTs for reducing global socioeconomic differences [60-62], students recognize that MOOCs help minimize the "digital divide", allowing access to existing information and resources on the web. In the same way, a positive perception was identified on the development of DTCs through the implementation of MOOCs, and of how such tools, when applied to the teaching of social sciences, power the creation of lesson plans that address the SDGs.

On the other hand, this study found a reverse correlation between the level of recognition and participation in MOOCs and the training of future teachers on technologies, in consideration of content, procedures, and values related to sustainable development. Thus, as indicated by Azcárate et al. [63], the incorporation of sustainability in the university curriculum has not occurred, and, as pointed out by Solís-Espallargas and Valderrama-Hernández [48], the majority of university teachers have still not accepted the process of including such content in teaching practice.

We can thus conclude by asserting, despite the perception of students who are future teachers, that MOOCs are very appropriate for their training; an underwhelming positive appraisal of the training received on sustainability and resources makes it difficult to include in the social science classroom. In this way, despite the proposals being implemented by education administrations for the inclusion of content and sustainable action in curricula and teacher training (CRUE, approved in 2005 and updated in 2012 for universities, and Order ECI/3858/2007 for secondary schools) [64], there is still a long way to go for the optimal formative training of university professionals, as to the current demands of society on this subject.

With regard to the limitations of this study, it is important to note that it is still in progress, as other dimensions remain to be analyzed. One option for the present research would be to apply a two-way ANOVA test, so as to simultaneously study the effects of two independent variables (gender and course of study) on the dependent variables being studied. Likewise, it is considered necessary to apply qualitative research techniques to deepen and expand the results of this initial study.

Similarly, the fact that the study sample came only from the University of Burgos and the University of Alicante is relevant, as this means that the results cannot be generalized to the entire teaching community of Spain. Furthermore, the sample was a convenient and non-probabilistic one, the resulting limitations of which are relevant when drawing general conclusions. We believe that it would be ideal to share the instrument with the remaining Spanish universities, so as to corroborate or refute the assessments presented here. Furthermore, it would be interesting to delve more deeply into how these perceptions materialize, such as in the practices of new teachers in schools, so as to confirm or refute some of the statements observed.

Author Contributions: Conceptualization, D.O.S.; methodology, D.O.S. and I.M.-G.T..; software, I.M.-G.T.; validation, I.M.-G.T.; formal analysis, D.O.S. and I.M.-G.T.; investigation, D.O.S. and I.M.-G.T.; resources, D.O.S. and I.M.-GT.; data curation, I.M.-G.T.; writing-original draft preparation, D.O.S.; writing-review and editing, D.O.S.; visualization, D.O.S; supervision, D.O.S.; project administration, D.O.S.

Funding: This investigation did not receive any specific subsidy by public, commercial, or non-profit institutions.

Conflicts of Interest: The authors declare no conflict of interest.

\section{References}

1. Mackness, J.; Mak, S.; Williams, R. The ideals and reality of participating in a MOOC. In Proceedings of the 7th International Conference on Networked Learning 2010; Dirckinck-Holmfeld, L., Hodgson, V., Jones, C., De Laat, M., McConnell, D., Ryberg, T., Eds.; University of Lancaster: Lancaster, UK, 2010; pp. 266-275.

2. Evans, S.; Myrick, J. How MOOC instructors view the pedagogy and purposes of massive open online course. Distance Educ. 2015, 36, 295-311. [CrossRef] 
3. Creed-Dikeogu, G. Are you MOOC—ing yet? A review for academic libraries. Kansas Library Assoc. College Univ. Libraries Sect. Proc. 2013, 3, 9-13.

4. Coakley, D.; Garvey, R.; O’Neill, Í. Micro-learning-Adopting Digital Pedagogies to Facilitate Technology-Enhanced Teaching and Learning for CPD. In Empowering 21st Century Learners Through Holistic and Enterprising Learning; Bee, G., Chee, S., Eds.; Springer: Berlin, Germany, 2016; pp. 272-275.

5. Bouchard, P. Network promises and their implications. Rev. Univ. Soc. Conoc. 2011, 8, 288-302.

6. Czerniewicz, L.; Deacon, A.; Glover, M.; Walji, S. MOOC-making and open educational practices. J. Comput. High. Educ. 2017, 29, 81-97. [CrossRef]

7. Ferreira, J.M.M. Massive Open Online Courses (MOOCs). In Cross-Border Higher Education and Quality Assurance; Sarrico, R.M., Tavares, O., Amaral, A., Eds.; Palgrave Macmillan: London, UK, 2016; pp. 203-219.

8. Godwin-Jones, R. Global reach and local practice: The promise of MOOCs. Lang. Learn. Technol. 2014, 18, 5-15.

9. Yuan, L.; Powell, S. MOOCs and Open Education: Implications for Higher Education; CETIS-University of Bolton: Bolton, UK, 2013.

10. Mcauley, A.; Stewart, B.; Siemens, G.; Cormier, D. Massive Open Online Courses. Digital Ways of Knowing and Learning. The MOOC Model for Digital Practice; University of Prince Edward Island: Charlottetown, PE, Canada, 2010; Available online: http:/ / davecormier.com/edblog/wp-content/uploads/MOOC_Final.pdf (accessed on 16 July 2018).

11. Sánchez-Vera, M.M.; González, V.; Prendes, M.P. Los MOOC y la evaluación del alumnado: Revisión sistemática (2012-2016). @tic revista d'innovació educativa. 2017, 18, 65-73. [CrossRef]

12. Aguaded, J.I.; Vázquez-Cano, E.; López-Meneses, E. El impacto bibliométrico del movimiento MOOC en la Comunidad Científica Española. Educación XX1. 2016, 19, 77-104. [CrossRef]

13. Hollands, F.; Tirthali, D. MOOCs: Expectations and Reality. Full Report; Columbia University: New York, NY, USA, 2014.

14. Glass, C.R.; Shiokawa-Baklan, M.S.; Saltarelli, A.J. Who Takes MOOCs? New Dir. Inst. Res. 2016, 167, 41-55. [CrossRef]

15. Poy, R.; Gonzales-Aguilar, A. Factores de éxito de los MOOC: Algunas consideraciones críticas. Iber. J. Inf. Syst. Technol 2014, E1, 105-118.

16. Ortega, D.; Gómez, I.M. Las WebQuests y los MOOCs en la enseñanza de las Ciencias Sociales y la formación del profesorado de Educación Primaria. Rev. Electró. Interuniv. Formación Profesorado. 2017, 20, 205-220. [CrossRef]

17. Ortega, D.; Gómez, I.; Moreno, J.R. Didáctica de la Geografía a través de Google Earth: MOOC para la formación del profesorado en Ciencias Sociales; Editorial Académica Española: Saarbrucken, Germany, 2016; ISBN 978-3-8417-6895-7.

18. Kop, R.; Fournier, H.; Mak, J.S.F. A pedagogy of abundance or a pedagogy to support human beings? Participant support on massive open online courses. Int. Rev. Res. Open Distrib. Lear. 2011, 12, 74-93.

19. Gyberg, P.; Löfgren, H. Knowledge outside the box-sustainable development education in Swedish schools. Educ. Res. 2016, 58, 283-299. [CrossRef]

20. Walshe, N. An interdisciplinary approach to environmental and sustainability education: Developing geography students' understandings of sustainable development using poetry. Environ. Educ. Res. 2017, 23, 1130-1149. [CrossRef]

21. Van Poeck, K.; Vandenabeele, J. Learning from sustainable development: Education in the light of public issues. Environ. Educ. Res. 2012, 18, 541-552. [CrossRef]

22. O'Flaherty, J.; Liddy, M. The impact of development education and education for sustainable development interventions: A synthesis of the research. Environ. Educ. Res. 2017, 23, 1-19. [CrossRef]

23. Gómez, I. Ma Proyecto a partir del modelo TPACK para desarrollar el aprendizaje de la Geografía en los estudios de Grado de Educación Primaria. Ph.D. Thesis, Universidad de Alicante, Alicante, Spain, 2015.

24. Argibay, J.C. Técnicas psicométricas. Cuestiones de validez y confiabilidad. Subj. Proces. Cognit. 2006, 8, 15-33.

25. Argibay, J.C. Muestra en investigación cuantitativa. Subj. Proces. Cognit. 2009, 13, 13-29.

26. Buendía, L.; Colás, M.P.; Hernández, F. Métodos de investigación en Psicopedagogía, 1st ed.; McGraw-Hill: Madrid, Spain, 1998; ISBN 448112547. 
27. Scheaffer, R.; Mendenhall, W.; Ott, L. Elementos de Muestreo; México, D.F., Ed.; Grupo Editorial Iberoamericano: Mexico City, Mexico, 1986; ISBN 9687270209.

28. Tashakkori, A.; Teddlie, C. Quality of inferences in Mixed Methods Research: Calling for an integrative framework. In Advances in Mixed Methods Research: Theories and Applications; Bergman, M., Ed.; Sage Publication, Inc.: Thousand Oaks, CA, USA, 2008; pp. 101-119.

29. Ato, M.; López, J.J.; Benavente, A. Un sistema de clasificación de los diseños de investigación en psicología. An. Psicol. 2013, 29, 1038-1059. [CrossRef]

30. Pardo, A.; Ruiz, M.A.; San-Martín, R. Análisis de datos en ciencias sociales y de la salud I.; Síntesis: Madrid, Spain, 2015; ISBN 9788497566476.

31. Hernández, R.; Fernández, C.; Baptista, P. Metodología de la Investigación; McGraw-Hill: México, Mexico, 2003; ISBN 9786071502919.

32. Bisquerra, R. Metodología de la Investigación Educativa, 1st ed.; La Muralla: Madrid, Spain, 2004; ISBN 8471337487.

33. UNESCO. Aprender a ser: La Educación del Futuro; UNESCO: Paris, France, 1972.

34. UNESCO. La Educación Encierra un Tesoro, Informe a la UNESCO de la Comisión Internacional sobre la Educación para el Siglo XXI.; UNESCO: Paris, France, 1996.

35. Díez Gutiérrez, E.J. Modelos socioconstructivistas y colaborativos en el uso de las TIC en la formación inicial del profesorado. Rev. Educ. 2012, 358, 175-196.

36. Cabero, J.; Llorente, M.C. La alfabetización digital de los alumnos. Competencias Digitales Para el Siglo XXI. 2008, 42, 7-28.

37. ONU. The Millennium Development Goals Report. 2015. Available online: http://www.un. org/millenniumgoals/2015_MDG_Report/pdf/MDG\%202015\%20rev\%20(July\%201).pdf (accessed on 3 December 2017).

38. ONU. Transforming our World: The 2030 Agenda for Sustainable Development (A/RE/70/1). 2015. Available online: http://www.un.org/ga/search/view_doc.asp?symbol=A/RES/70/1\&Lang=E (accessed on 3 December 2017).

39. Mayor, F. La problemática de la sostenibilidad en un mundo globalizado. Rev. Educ. 2009, 1, $25-52$.

40. Bonil, J.; Junyent, M.; Pujol, R.M. Educación para la Sostenibilidad desde la perspectiva de la complejidad. Revista Eureka sobre Enseñanza y Divulgación de las Ciencias. 2010, 7, 198-215. [CrossRef]

41. Buchberger, F.; Campos, B.P.; Kallos, D.; Stephenson, J. Green Paper on Teacher Education in Europe; Thematic Network on Teacher Education in Europe: Umeå, Sweden, 2000; ISBN 9197390402.

42. Cabero, J.; Marín, V. Miradas sobre la formación del profesorado. TIC. Revista venezolana de Información, Tecnología y Conocimiento. 2014, 11, 11-24.

43. Mir, A. Las competencias transversales en la Universidad Pompeu Fabra. La visión de los docentes y estudiantes de segundo ciclo. RedU. Revista de Docencia Universitaria. 2008, 6. [CrossRef]

44. Rodríguez-García, M.; Martínez, N.; Raso, F. La formación del profesorado en competencia digital: Clave para la educación del siglo XXI. Revista Internacional de Didáctica y Organización Escolar. 2017, 3, 46-65.

45. CADEP-CRUE. Directrices Para la Introducción de la Sostenibilidad en el Curriculum. 2012. Available online: https:/ / www.crue.org/Documentos\%20compartidos/Declaraciones/Directrices_Sosteniblidad_ Crue2012.pdf (accessed on 15 October 2017).

46. Marín, V.; Vázquez, A.I.; Llorente, M.C.; Cabero, J. La alfabetización digital del docente universitario en el Espacio Europeo de Educación Superior. Edutec. Revista Electrónica de Tecnología Educativa. 2012, 39, 194.

47. Roig-Vila, R.; Mengual-Andrés, S.; Sterrantino, C.; Quinto, P. Actitudes hacia los recursos tecnológicos en el aula de los futuros docentes. @tic. Revista d'innovació educativa. 2015, 15, 12-19. [CrossRef]

48. Solís-Espallargas, C.; Valderrama-Hernández, R. La educación para la sostenibilidad en la formación de profesorado. ¿Qué estamos haciendo? Foro de Educación. 2015, 13, 165-192. [CrossRef]

49. Emine, K.; Emre, N.; Kamil, N. Creencias sobre alfabetización mediática en profesores y estudiantes de Educación Primaria. Comunicar 2014, 21, 119-127. [CrossRef]

50. Cabero, J. Formación del profesorado en TIC. El gran caballo de batalla. Comunicación y Pedagogía: Revista de Nuevas Tecnologías y Recursos Didácticos. 2004, 195, 27-37.

51. Cabezas, M.; Casillas, S.; Pinto, A.M. Percepción de los alumnos de Educación Primaria de la Universidad de Salamanca sobre su competencia digital. EDUTEC, Revista Electrónica de Tecnología Educativa. 2014, 48, 275. 
52. Prendes, M.P.; Castañeda, L.; Gutiérrez, I. Competencias para el uso de TIC de los futuros maestros. Comunicar 2010, 18, 175-182. [CrossRef]

53. Mora, W.M. Respuesta de la universidad a los problemas socioambientales: La ambientalización del currículo en la educación superior. Investigación en la escuela. 2007, 62, 65-76.

54. Sampedro, B.E. Las TIC y la educación social en el siglo XXI. EDMETIC, Revista de Educación Mediática y TIC. 2016, 5, 8-24. [CrossRef]

55. Ull, M.; Martínez, M.; Piñero, A.; Aznar, P. Análisis de la introducción de la Sostenibilidad en la Enseñanza Superior en Europa: Compromisos y propuestas curriculares. Revista Eureka sobre Enseñanza y Divulgación de las Ciencias. 2010, 7, 413-432. [CrossRef]

56. Vilches, A.; Gil, D. ¿Cómo puede contribuir la educación a la construcción de un futuro sostenible? Revista Eureka Enseñanza y Divulgación de las Ciencias. 2010, 7, 388-399. [CrossRef]

57. Erdogan, A.; Sahin, I. Relationship between Math Teacher Candidates' Technological Pedagogical a Content Knowledge (TPACK) and Achievement Levels. Procedia-Soc. Behav. Sci. 2010, 2, 2707-2711. [CrossRef]

58. Minget, P.A.; Solís, A.U. La formación de competencias básicas para el desarrollo sostenible: El papel de la Universidad. Revista de Educación 2009, 219-237.

59. Gómez, I.M.; Ortega, D. Los MOOC en la Didáctica de la Geografía: Aplicaciones en la formación inicial del profesorado de Primaria. In Nuevas Perspectivas Conceptuales y Metodológicas para la Educación Geográfica; Martínez, E., Tonda, E., Eds.; Grupo de Didáctica de la Geografía de la Asociación de Geógrafos Españoles Córdoba: Madrid, Spain; pp. 229-244.

60. ITU. ICT Facts and Figures 2017. 2017. Available online: https://www.itu.int/en/ITU-D/Statistics/Pages/ facts/default.aspx (accessed on 9 April 2018).

61. ITU. Measuring the Information Society Report. 2017. Available online: https://www.itu.int/en/ITU-D/ Statistics/Pages/publications/mis2017.aspx (accessed on 9 April 2018).

62. ITU. The ICT Development Index (IDI). 2017. Available online: https://www.itu.int/net4/ITU-D/idi/2017/ index.html\#idi2017economycard-tab\&BRA (accessed on 9 April 2018).

63. Azcárate, P.; Navarrete, A.; García, E. Aproximación al nivel de inclusión de la sostenibilidad en los curricula universitarios. Profesorado 2012, 16, 105-119.

64. Orden ECI/3858/2007. de 27 de Diciembre, por la que se Establecen los Requisitos para la Verificación de los de los Títulos Universitarios Oficiales que Habiliten Para el Ejercicio de las Profesiones de Profesor de Educación Secundaria Obligatoria y Bachillerato. Formación profesional y Enseñanzas de Idiomas; Boletín Oficial del Estado: Madrid, Spain, 2007; p. 312, de 29 de diciembre de 2007.

(C) 2019 by the authors. Licensee MDPI, Basel, Switzerland. This article is an open access article distributed under the terms and conditions of the Creative Commons Attribution (CC BY) license (http://creativecommons.org/licenses/by/4.0/). 